\title{
Central relaxin-3 receptor (RXFP3) activation impairs social recognition and modulates ERK-phosphorylation in specific GABAergic amygdala neurons
}

Hector Albert-Gasco ${ }^{1} \dagger$, Sandra Sanchez-Sarasua ${ }^{1}$, Sherie $\mathrm{Ma}^{2} \S$, Cristina García-Díaz ${ }^{1}$, Andrew L. Gundlach ${ }^{2}$, Ana M. Sanchez-Perez ${ }^{1 *}$, Francisco E. Olucha-Bordonau* ${ }^{1 *}$

${ }^{1}$ Departamento de Medicina, Facultad de Ciencias de la Salud, Universitat Jaume I, Castellón, España (Spain)

${ }^{2}$ The Florey Institute of Neuroscience and Mental Health, Parkville, Victoria, Australia and Florey Department of Neuroscience and Mental Health, The University of Melbourne, Victoria, Australia

$\dagger$ Present Address: Department of Clinical Neurosciences, University of Cambridge, Cambridge, United Kingdom

$\S$ Present Address: Drug Discovery Biology, Monash Institute of Pharmaceutical Sciences, Monash University, Parkville, Victoria, Australia

*Authors for correspondence: Av de Vicent Sos Baynat, s/n 12071 Castellón de la Plana, Spain Email: folucha@med.uji.es and sanchean@med.uji.es

Phone: +3496472 7459, +34964727460

\section{AKNOWLEDGEMENTS}

The authors thank Dr Mohammad Akhter Hossain (The Florey Institute of Neuroscience and Mental Health, Parkville, Australia) for providing the RXFP3-A2 peptide used in these studies. This research was supported by the following grants: Universitat Jaume I research grant UJIB2016-40 and Program of Mobilities of the Spanish Ministerio de Educación y Cultura, PRX17/00646 (FEO-B); Universitat Jaume I FPI-UJI Predoctoral Research Scholarship PREDOC/2014/35 (HAG); E-2016-43 Research Travel Grant (HAG); Plan Propi Universitat Jaume I P1.1A2014-06 (AMS-P); NHMRC (Australia) Project Grant 1067522 (ALG); and Dorothy Levien Foundation research grant (ALG). 


\begin{abstract}
In mammals, the extended amygdala is a neural hub for social and emotional information processing. In the rat, the extended amygdala receives inhibitory GABAergic projections from the nucleus incertus (NI) in the pontine tegmentum. NI neurons produce the neuropeptide relaxin-3, which acts via the $\mathrm{G}_{\mathrm{i} / \mathrm{o}}$-protein-coupled receptor, RXFP3. A putative role for RXFP3 signalling in regulating social interaction was investigated by assessing the effect of intracerebroventricular infusion of the RXFP3 agonist, RXFP3-A2, on performance in the 3chamber social interaction paradigm. Central RXFP3-A2, but not vehicle, infusion, disrupted the capacity to discriminate between a familiar and novel conspecific subject, but did not alter differentiation between a conspecific and an inanimate object. Subsequent studies revealed that agonist-infused rats displayed increased pERK-immunoreactivity in specific amygdaloid nuclei at 20 min post-infusion, with levels similar to control again after $90 \mathrm{~min}$. In parallel, we used immunoblotting to profile ERK phosphorylation dynamics in whole amygdala after RXFP3A2 treatment; and multiplex histochemical labelling techniques to reveal that after RXFP3-A2 infusion and social interaction, pERK-immunopositive neurons in amygdala expressed vesicular GABA-transporter mRNA and displayed differential profiles of RXFP3 and oxytocin receptor mRNA. Overall, these findings demonstrate that central relaxin-3/RXFP3 signalling can modulate social recognition in rats via effects within the amygdala and likely interactions with GABA and oxytocin signalling.
\end{abstract}

$(210 / 250$ words $)$

Key words: Arousal, Emotion, Nucleus incertus, Oxytocin receptor 


\section{INTRODUCTION}

The capacity to identify and recall familiar conspecifics is crucial for appropriate social interaction and its absence is associated with impaired social abilities ranging from borderline personality disorder (Servan et al. 2017) to schizophrenia (Davis et al. 2014; Green et al. 2015) and autism spectrum disorders (Happé and Conway 2016). Social identification of conspecifics is intimately related to social recognition memory (SRM), a key process underlying long-term, socially-related behaviours, including pair bonding, aggression and mating (Dantzer et al. 1987; Gheusi et al. 1994; Williams et al. 2006; Maski et al. 2015). The amygdala is responsible for recognition of emotional facial expressions in humans (Baxter and Murray 2002; Seymour and Dolan 2008; Vuilleumier and Sander 2008; Gupta et al. 2011; Benarroch 2015; Bonnet et al. 2015) and social relationship pair-bonding in humans and rodents (Gobrogge et al. 2009; Hurlemann et al. 2010).

In rodents, conspecifics are recognized by olfactory information entering the amygdala from the main and accessory olfactory bulbs (Scalia and Winans 1975; Ferguson et al. 2001; Pro-Sistiaga et al. 2007; Trainor et al. 2010). Within the amygdala, the medial (MeA) nuclei and the bed nucleus of the stria terminalis (ST) ${ }^{1}$, process social cues (Alheid et al. 1998; RasiaFilho et al. 2000; Alheid 2006; Pereira et al. 2013; Fox et al. 2015) and, in turn, send projections to the hypothalamus (Hatalski et al. 1998; Smith and Vale 2006; Veenema 2008) and hippocampus (Hitti and Siegelbaum 2014; Okuyama et al. 2016). Ascending monoaminergic projections from neurons located in the brainstem also modulate aspects of social behaviour (Korzan et al. 2001; Arakawa 2017).

In a similar fashion, neurons in the nucleus incertus (NI), located in the pontine tegmentum, innervate the amygdala and other regions involved in social behaviour (Olucha-Bordonau et al. 2003; Ryan et al. 2011; Santos et al. 2016). The NI is characterized by GABA neurons that coexpress relaxin-3 (RLN3), a member of the insulin/relaxin superfamily (Bathgate et al. 2002; Burazin et al. 2002; Ma et al. 2007, 2017). The impact of the NI GABA/RLN3 system on amygdala and extended amygdala-related behaviours has been described in various paradigms, including fear acquisition (Lee et al. 2014), extinction (Pereira et al. 2013), anxiety (Ryan et al. 2013a), feeding (Lenglos et al. 2014), and alcohol-seeking (Ryan et al. 2013b).

RLN3 is the cognate ligand of relaxin-family peptide receptor 3 (RXFP3), which is a $\mathrm{G}_{\mathrm{i} / \mathrm{o}^{-}}$ protein-coupled receptor (Bathgate et al. 2002; Liu et al. 2003). Recent studies indicate that RXFP3 activation predominantly produces hyperpolarization of RXFP3 mRNA-positive neurons in rat brain slices, including magnocellular and parvocellular oxytocin neurons (Blasiak et al. 2013; Kania et al. 2017), consistent with inhibition of adenylate cyclase and reduced cellular cAMP levels associated with $\mathrm{G}_{\mathrm{i} / \mathrm{o}}$-coupled receptor activation in cell-based systems (Liu et al. 2003; Halls et al. 2007). RXFP3 activation rapidly activates cellular externally-regulated kinases (ERKs) in vitro (Van der Westhuizen et al. 2007, 2010; Kocan et al. 2014); and in vivo, intracerebroventricular (icv) RXFP3 agonist injection produced increased levels of phosphorylated ERK (pERK) in rat medial septal cholinergic neurons (Albert-Gascó et al. 2017). However, this specific effect is thought to be indirect, as septal and diagonal band cholinergic neurons have been confirmed to be RXFP3 mRNA-negative (Albert-Gascó et al. 2018). Nonetheless, altered pERK levels in the amygdala have been associated with social interaction behaviour (Richter et al. 2005; Peng et al. 2010; Giese and Mizuno 2013) and changes in pERK levels have been used to assess brain activity changes underlying behavioural social deficits (Faridar et al. 2014).

\footnotetext{
1 The bed nucleus of the stria terminalis is abbreviated as BNST, BST or ST. However, when describing subdivisions of the area, the abbreviations become long and less useful. Thus, in the 7th Edition of The Rat Brain in Stereotaxic Coordinates, the whole bed nucleus of the stria terminalis was abbreviated as ST (Olucha-Bordonau et al. 2014; Paxinos and Watson 2014).
} 
We hypothesized that RXFP3 activation could modulate social recognition and/or recall of SRM. Thus, we examined the effects of icv infusion of the selective RXFP3 agonist, RXFP3A2 (Shabanpoor et al. 2012; Zhang et al. 2015), on social discrimination performance in the 3chamber paradigm; and levels of pERK in the extended amygdala. Subsequently, we studied the relationship between behavioural responses and the occurrence of pERK immunoreactivity in RXFP3 mRNA-expressing neurons. In addition, we investigated the anatomical association of RLN3-positive nerve fibres with activated neurons in the amygdala, reflected by neuronal pERK immunostaining. Finally, we assessed the neurochemical phenotype of RXFP3 mRNApositive neurons in the extended amygdala by assessing the relative co-expression of $R x f p 3$ mRNA with vesicular GABA-transporter (SlC32al) and oxytocin receptor (Oxtr) mRNA. Overall, our findings suggest a role for RLN3/RXFP3 signalling in modulating social memory, which might occur via rapid alterations in ERK and related signalling in GABAergic and Oxtrpositive neurons within specific regions of the extended amygdala.

\section{MATERIALS AND METHODS}

\section{Animals and surgical procedures}

The Ethics Committee of the University Jaume I approved all procedures (\#2015/VSC/PEA/00091). Male, Wistar rats (300-380g) were maintained on a 12-12 h lightdark cycle with lights on at $0700 \mathrm{~h}$ GMT and behavioural procedures were conducted between 10.00 and $12.00 \mathrm{~h}$ GMT.

For surgical procedures, rats were anesthetised with ketamine (Imalgene $25 \mathrm{mg} / \mathrm{kg}$ i.p., Merial-Laboratories-SA, Barcelona, Spain) and xylazine $(10 \mathrm{mg} / \mathrm{kg}$, i.p., X1251 SigmaAldrich, St Louis, MO, USA), and then a cannula was implanted at stereotaxic coordinates AP $0.48 \mathrm{~mm}$, ML $0.1 \mathrm{~mm}$, DV $-4 \mathrm{~mm}$ from bregma (Paxinos and Watson 2014) and secured with a screw attached to the skull.

\section{Experimental groups}

In this study, six experimental treatment groups were used. Apart from those in the nä̈ve group, all rats had a cannula implanted targeting the right lateral cerebral ventricle.

Agonist-infused and vehicle groups used for immunoblotting studies, which did not undergo behavioural testing, were killed 20 and $90 \mathrm{~min}$ after peptide or vehicle infusions. Alternatively, infusions of agonist and vehicle rat groups which did undergo a 3-chamber social interaction behavioural test, were made either 20 minutes prior the Sociability test, agonist infused animals were named RXFP3-A2-Soc (A2-Soc), or 20 minutes prior to the Preference test, agonist infused animals were named RXFP3-A2-Pref (A2-Pref) (Fig. 1a).

On all cases, infusions were done one week after surgery, when the vehicle experimental group received $1 \mu \mathrm{l}$ of artificial cerebrospinal fluid (aCSF) and agonist experimental groups received $1 \mu 1$ of $5 \mu \mathrm{g} / \mu 1$ of RXFP3-A2 [R3A(11-24, C15 $\rightarrow$ A)B] specific RXFP3 agonist solution (Shabanpoor et al. 2012). Infusions were done at a rate of $0.5 \mu 1 / \mathrm{min}$ over 2 minutes using a Harvard syringe injector (Harvard PHD2000 syringe pump; Harvard Apparatus, Holliston, MA, USA). After infusions, the injector needle was left in place for 5 minutes to avoid reflux of agonist or vehicle.

RXFP3-A2 agonist was kindly supplied by A/Prof M Akhter Hossain (The Florey Institute of Neuroscience and Mental Health, Parkville, Australia). 


\section{Three-chamber social interaction and memory test}

All rats were handled daily during the week after surgery. On the day of the behavioural test, rats were habituated to the behavioural room for $30 \mathrm{~min}$ before the vehicle or peptide infusions $20 \mathrm{~min}$ prior to each trial. The behavioural test was conducted in a three-chamber apparatus. Each chamber measured $22 \times 39 \times 40 \mathrm{~cm}$. On the first trial, following a $5 \mathrm{~min}$ habituation, each rat was allowed to explore either a conspecific or an inanimate object for $10 \mathrm{~min}$ ('Sociability Test'). After a $1 \mathrm{~h}$ inter-trial period, in the 'Preference Test' each test rat was allowed to explore a familiar conspecific (from the sociability test) or a novel one for $10 \mathrm{~min}$. The chamber in which the novel (stranger) rat or object were placed were balanced every two cases (agonist infused and control subject) in all experiments. In addition, the rat acting as stranger was also balanced every two cases. Finally, animals acting as subject on the sociability test were then change to the opposite position on the preference test. Behaviour was analysed using videotracking (Supplementary Fig. 1a, b). Rats were killed immediately after the preference test. Data were expressed as either a "sociability index", which was calculated as the time spent sniffing the subject minus the time sniffing the object (sociability test), or the "preference index", calculated as the time sniffing the novel conspecific minus the time sniffing the familiar conspecific (preference test) (Fig. 1a). Data were analysed by one way-ANOVA followed by a Bonferroni post-hoc test. First contact latencies, as a measure of social anxiety, was used for both for the Social interaction test and the Preference test. The contact was considered when rats being tested sniffed a conspecific, was expressed in seconds and compared between the different behavioural groups.

\section{Immunoblotting}

In western blot studies, pERK levels were assessed in the amygdaloid complex, as described (Albert-Gascó et al. 2017). In brief, rats were lightly anesthetized (Dolethal, $200 \mathrm{mg} / \mathrm{Kg}$ Vetoquinol S.A., Madrid, Spain) and then killed by decapitation. Brains were removed and frozen. The amygdala was dissected using $1 \mathrm{~mm}$ diameter disposable biopsy punches (Interna Miltex, Ratingen, Germany) from $20 \mu \mathrm{m}$ brain slices cut using a cryostat at $-15^{\circ} \mathrm{C}$ to preserve protein phosphorylation. Brain tissue samples were lyzed in RIPA buffer containing protease and phosphatase inhibitors (Halt \#78440 protease and phosphatase inhibitor, Thermo Scientific, Waltham, MA, USA).

Equal amounts of total protein were loaded onto a polyacrylamide gel, resolved and transferred to Immobilon-P membranes (MERCK Millipore, Darmstadt Germany), followed by blocking with bovine serum albumin. Membranes and primary antibodies (anti-pERK antibody (E-4) Santa Cruz Biotechnology sc-7383, Santa Cruz, CA, USA; 1:500) and anti-ERK (Santa Cruz Biotechnology SC-7383; 1:1,000), were incubated overnight at $4^{\circ} \mathrm{C}$ and for $1 \mathrm{~h}$ at room temperature with peroxidase-conjugated secondary antibodies (anti-rabbit and antimouse, Jackson Immunoresearch, West Grove, PA, USA). Bands were developed using enhanced chemiluminescence (BioRad, Hercules CA, USA) and digital images were captured with a charge-coupled device imager (IMAGEQUANT LASc 4000, GE Healthcare Little Chalfont, UK). Immunoreactive bands were quantified with ImageJ blots toolkit software (National Institutes of Health, Baltimore, MD, USA). The intensity of the pERK bands was measured and normalized to the ERK band intensity, and data were expressed as the $\mathrm{pERK} / \mathrm{ERK}$ ratio for each treatment, relative to that of the naïve rat group. Data were analyzed by one way-ANOVA followed by Bonferroni post-hoc test.

\section{Immunohistochemistry and immunofluorescence staining}

Immunohistochemistry and immunofluorescence analysis were performed as described (Albert-Gascó et al. 2017). Briefly, the RXFP3-A2 and naïve groups ( $\mathrm{n}=6$-8/group) were euthanized with sodium pentobarbital $(120 \mathrm{mg} / \mathrm{kg}$, Eutanax, Fatro, Barcelona, Spain) and 
transcardially with saline $(0.9 \% \mathrm{NaCl})$ followed by fixative $(4 \%$ paraformaldehyde in $0.1 \mathrm{M}$ $\mathrm{PB}, \mathrm{pH} 7.4)$ for $30 \mathrm{~min}(* 600 \mathrm{~mL}$ per rat). Brains were then removed and immersed in fixative for $4 \mathrm{~h}$ at $4^{\circ} \mathrm{C}$. Subsequently, brains were cryoprotected in $30 \%$ sucrose in $0.01 \mathrm{M}$ phosphatebuffered saline $\mathrm{p} \mathrm{H} 7.4$ for 3 days.

Coronal sections $(40 \mu \mathrm{m})$ from bregma $0.36 \mathrm{~mm}$ to $-3.6 \mathrm{~mm}$ (Paxinos and Watson 2014) were obtained using a freezing slide microtome (Leica SM2010R, Heidelberg, Germany) and stored in sucrose-PBS. After incubation in blocking solution $(10 \% \mathrm{NGS}$, in $0.1 \mathrm{M} \mathrm{PBS}, 0.3 \%$ Triton X-100, $\mathrm{pH}$ 7.6) sections were incubated overnight at room temperature with rabbit antiphospho-MAPK/ERK (\#9101 Cell Signalling, Danvers, MA, USA; 1:200) and mouse antiRLN3 (Tanaka et al. 2005); 1:5) in blocking solution.

For immunochemistry of pERK, after several rinses in PBS, sections were incubated for 1 $\mathrm{h}$ in 1:200 biotinylated goat anti-rabbit secondary antibody (Jackson Immunoresearch, 111065-003), rinsed and transferred to avidin-biotin complex (Vectastain-Elite, Cat No. PK-6100; Vector Laboratories, Burlingame, CA, USA). Labelling was visualized with $0.025 \%$ DAB, $0.0024 \% \mathrm{H}_{2} \mathrm{O}_{2}$ in Tris- $\mathrm{HCl}$ buffer, $\mathrm{pH}$ 7.6. After final washes, sections were mounted, air-dried, dehydrated and coverslipped with DPX (Sigma-Aldrich). Quantification of pERK-positive neurons was conducted using ImageJ (National Institutes of Health). Data were expressed as the number of pERK-positive neurons/area and normalized to values observed in vehicle rats.

Double-labeling immunofluorescence, was completed as described (Albert-Gascó et al. 2017) Briefly, sections were incubated with primary antisera and then with goat anti-rabbit Cy3 and goat anti-mouse Alexa Fluor 488 (Jackson Immunoresearch; \#111-165-003, \#115-545003). Following further rinsing, sections were mounted on slides and coverslipped using Fluoromount-G (\#0100-01, Southern Biotech, Birmingham, AL, USA).

\section{Multiplex in situ hybridization}

In studies to evaluate ERK activation in RXFP3 mRNA-positive neurons, we combined detection of pERK immunofluorescence with in situ hybridization (ISH) detection of $R x f p 3$ mRNA-positive neurons, using fluorescence ISH (RNAscope ${ }^{\mathrm{TM}}$; Advanced Cell Diagnostics (ACD); Newark, CA, USA). After behavioural testing, rats were transcardially perfused, as described (Albert-Gascó et al. 2017). After $18 \mathrm{~h}$ post-fixation at $4^{\circ} \mathrm{C}$, brain sections $(30 \mu \mathrm{m})$ were collected using a vibratome (Leica VT $1200 \mathrm{~S}$, Wetzlar Germany) and transferred to a cryprotectant medium (30\% ethylene glycol, 30\% glycerol in phosphate buffer, $\mathrm{pH} 7.4$ ) and stored at $-20^{\circ} \mathrm{C}$.

For the detection of $R x f p 3$ mRNA, probes covered $\sim 1000$ bp of the target mRNA. Sections were mounted onto Superfrost Plus Slides (Fisher Thermo Scientific, Hampton, NH, USA, Cat\#12-550-15) and air dried. The next day, sections were fixed in 4\% formaldehyde for 10 min at $4^{\circ} \mathrm{C}$, and rinsed in PBS. Once dry, a hydrophobic barrier was drawn around the sections (ImmEdge hydrophobic PAP pen, Vector Laboratories, \#310018). Sections were incubated with protease pretreatment-4 (ACD, Cat $\# 322340$ ) for $30 \mathrm{~min}$ at $40^{\circ} \mathrm{C}$. After a distilled water rinse, sections were incubated for $2 \mathrm{~h}$ at $40^{\circ} \mathrm{C}$ with $\operatorname{Rxfp} 3 \mathrm{mRNA}$ probe (ACD, \#316181). Following incubation, sections were rinsed with wash buffer (\#310091) and the signal was amplified with ACD amplifier reagents. After several rinses in wash buffer and PBS, sections were incubated for immunofluorescence against pERK, with anti-phospho-MAPK/ERK (Cell Signaling 1:50) for $90 \mathrm{~min}$ at room temperature and Cy3 goat anti-rabbit IgG for $30 \mathrm{~min}$.

The neurochemical phenotype of $R x f p 3$ mRNA-expressing neurons was assessed using multiplex fluorescence ISH (RNAscope, ACD) using probes targeting Rxfp3 (\#316181), Oxtr (\#483671) and Slc32al (\#415681) mRNA, as described (Albert-Gascó et al. 2018). 


\section{Confocal analysis}

Confocal analysis was performed as described (Albert-Gascó et al. 2017). Briefly, immunofluorescence images were captured with a Leica DMi8 inverted microscope (Leica Microsystems) at $0.3 \mu \mathrm{m}$ interval stacks. Immunofluorescent neurons were counted using ImageJ software (National Institutes of Health). Percentages of co-expression between pERK and Rxfp3 mRNA positive neurons in brains from the A2-pref group were compared to the vehicle-treatment group, using a Mann-Whitney test $(n=4)$.

Similarly, ISH images were captured using an LSM 780 Zeiss Axio Imager 2 confocal laser-scanning microscope (Carl Zeiss AG, Jena, Germany). This system is equipped with a stitching stage, and Zen software (Carl Zeiss AG) was used to stitch tiled images taken with a $20 \times$ objective or $40 \times$ objective. Quantification of co-expression ( 1 section per level and per rat) was conducted manually using Fiji (Schindelin et al. 2012), with labeling with each probe counted separately, relative to DAPI-stained nuclei, to avoid bias.

\section{RESULTS}

\section{Icv RXFP3-A2 infusion impaired social recognition memory}

Previous studies have described robust effects of icv infusion of RXFP3 agonists within 20 min post-infusion (Ryan et al. 2013a; Albert-Gascó et al. 2017; de Ávila et al. 2018). Thus, we designed a schedule in which icv infusion of the agonist, RXFP3-A2 or vehicle, was administered $20 \mathrm{~min}$ prior to the social or preference tests.

RXFP3 agonist treatment did not alter responses in the sociability test, as all groups of rats spent an average $78.4 \pm 2.6 \%$ of the 10 minute duration of the test sniffing the conspecific rat and the sociability index was not significantly different across all groups $\left(F_{2,23}=0.30 ; p=0.74\right.$, Fig. 1b; Supplementary Fig. 1c). However, RXFP3 agonist infusion before the sociability test (A2-Soc) or the preference test (A2-Pref) significantly altered the preference index, which was positive for control groups (naïve: $0.35 \pm 0.06, \mathrm{n}=6$; vehicle: $0.33 \pm 0.07, \mathrm{n}=5$ ), but negative for the A2-Pref $(-0.14 \pm 0.05, \mathrm{n}=5)$ and A2-Soc $(-0.13 \pm 0.06, \mathrm{n}=6)$ groups, $\left(\mathrm{F}_{3,21}=19.14, \mathrm{p}\right.$ $<0.0001$; Fig. 1c); indicating that agonist-treated rats had no preference for novelty. This response can be interpreted as a deficit in recalling the familiar rat. Control groups spent $>60 \%$ of the test duration exploring the novel conspecific, which is indicative of social memory of the familiar rat and preference to explore the novel rat. In contrast, agonist-treated rats spent a significantly longer time exploring the familiar rat (Supplementary Fig. 1d). Furthermore, the time exploring the familiar rat was not $>60 \%$ of the test duration, ruling out any 'bonding' to the familiar conspecific. Lastly, RXFP3-A2-treated rats did not display increased locomotor activity compared to control groups (data not shown). When analysing social interaction first contact latencies A2-Soc groups $(8.8 \mathrm{~s} \pm 3.6 \mathrm{~s}, \mathrm{n}=5)$ did not show a significative difference with either vehicle $(10.27 \mathrm{~s} \pm 2.7 \mathrm{~s}, \mathrm{n}=10)$ nor Naïve groups $(13.84 \mathrm{~s} \pm 4.3 \mathrm{~s} ; \mathrm{n}=6)\left(\mathrm{F}_{3,26}=0,41, \mathrm{p}=\right.$ 0,67 ; Fig 1d). In a similar manner, in the Preference test, A2-Soc $(4.01 \mathrm{~s} \pm 1.1 \mathrm{~s}, \mathrm{n}=5)$ and A2Pref $(4.755 \mathrm{~s} \pm 1.1 \mathrm{~s}, \mathrm{n}=8)$ subjects did not show differential latencies with vehicle nor Naïve rats $(3.8 \mathrm{~s} \pm 0.9 \mathrm{~s}, \mathrm{n}=6)\left(\mathrm{F}_{3,27}=0.59, \mathrm{p}=0.63\right.$; Fig.1e). Rats any condition did not show social anxiety as no significative differences were observed when comparing the different experimental groups first contact latencies.

\section{Icv RXFP3-A2 infusion rapidly increased ERK phosphorylation in amygdala}

Using western immunoblotting, we quantified ERK and pERK levels in amygdala tissue extracts from rats killed 20 and 90 min after RXFP3-A2 or aCSF infusions, and from naïve, untreated rats (Fig. 2). All data followed a normal distribution according to a Shapiro-Wilk normality test. When compared to naïve rats $(1.00 \pm 0.07, \mathrm{n}=8)$, rats receiving an aCSF infusion $20 \mathrm{~min}$ before perfusion did not display a significant increase in pERK levels $(1.20 \pm$ 
$0.08, \mathrm{n}=8)$. In contrast, rats that received RXFP3 agonist infusion (A2-20) displayed a significant increase of $\mathrm{pERK}$ levels $(1.79 \pm 0.2, \mathrm{n}=7)$ compared to naïve and aCSF-treated rats $\left(F_{2,22}=10.29, p=0.0008\right.$; Fig. 2a, b). However, rats treated with the agonist 90 min prior to perfusion (A2-90) displayed a similar $\mathrm{pERK} / \mathrm{ERK}$ ratio to naïve and aCSF-treated rats $(0.9 \pm$ $0.02, \mathrm{n}=5 ; \mathrm{F}_{2,14}=1.00, \mathrm{p}=0.39 ;$ Fig. 2c, d).

Icv RXFP3-A2 infusion increased pERK immunoreactivity in discrete amygdaloid nuclei after the three-chamber social interaction and memory test

We assessed the effect of icv RXFP3-A2 infusion on cellular pERK levels in specific amygdaloid nuclei after the three-chamber social interaction test (Table 1). For analysis, the amygdala was considered in two parts: the rostral extension containing the bed nucleus of the stria terminalis (ST); and the temporal extension containing the medial amygdala (MeA) (Olucha-Bordonau et al. 2014). Within the MeA (Fig. 3a), significantly increased pERK (Fig. 3b) was observed in the anterior dorsal part (MeAD) in the A2-Pref group $(190 \pm 28.0 \%, \mathrm{n}=$ 6) compared to the vehicle-treated $(100 \pm 15.4 \%, \mathrm{n}=6)$ and A2-Soc $(101 \pm 21.5 \%, \mathrm{n}=5)$ groups $\left(\mathrm{F}_{2,16}=5.49, \mathrm{p}=0.017\right.$; Fig. 3c-e). Similarly, significantly increased pERK (Fig. 3b) was observed in the posterior ventral part (MePV) of the A2-Pref group $(177.3 \pm 18.9 \%, \mathrm{n}=$ 8), compared to the vehicle-treated $(100 \pm 19.4 \%, \mathrm{n}=6)$ and A2-Soc $(133.4 \pm 22.3 \%, \mathrm{n}=6)$ groups $\left(\mathrm{F}_{2,18}=4.07, \mathrm{p}=0.037\right.$; Fig. 3f-h $)$. All other regions examined, did not exhibit significant differences in cellular pERK levels, across the groups (Table 1).

In the ST (Fig. 4a), rats in the A2-Pref group displayed a significantly higher density of pERK-positive neurons in the ventral part (STMV) $(275 \pm 27.2, \mathrm{n}=8$; Fig. 4b) compared to the A2-Soc $(196 \pm 49.0, \mathrm{n}=5)$ and vehicle $(100 \pm 21.9, \mathrm{n}=6)$ groups $\left(\mathrm{F}_{2,18}=8.10, \mathrm{p}=0.04\right.$; Fig. 4c-e). The A2-Pref group also displayed a significantly increased density of pERK-positive neurons in the oval nucleus (STOV) $(198 \pm 29.0, \mathrm{n}=5)$ compared to the vehicle $(100 \pm 10.7, \mathrm{n}$ $=5)$ and A2-Soc $(118.5 \pm 8.50, \mathrm{n}=5)$ groups $\left(\mathrm{F}_{2,11}=6.10, \mathrm{p}=0.02 ;\right.$ Fig. 4f-h $)$.

Using dual immunofluorescence detection of pERK and RLN3, we demonstrated putative close contacts between RLN3-immunoreactive fibres and pERK-positive neurons in the MeAD (Fig. 3i, i'), MePV (Fig. 3j, j') and STMV (Fig. 4j, j') in the A2-Pref group. (Densities of pERK-immunopositive neurons followed a normal distribution according to a Shapiro-Wilk normality test).

\section{$R x f p 3$ mRNA-positive neurons in amygdala display increased pERK immunoreactivity after three-chamber social interaction testing}

We conducted the three-chamber social interaction test in a separate cohort of rats and assessed neuronal co-expression of Rxfp3 mRNA and pERK immunofluorescence (Fig. 5a-b). In the $\mathrm{MeA}$, the density of Rxfp3 mRNA- and pERK immunopositive neurons, was significantly higher in the A2-pref group than the vehicle group, in both the MeAD $(27.5 \pm 2.9 \%$ A2-pref vs $7.25 \pm 1.25 \%$ vehicle; $n=4 ; p<0.05$; Fig. 6a-b"), and the MePV (34.5 $\pm 5.7 \%$ A2-pref vs 6.75 $\pm 1.8 \%$ vehicle; $\mathrm{n}=4 ; \mathrm{p}<0.05$; Fig. 6c-d").

Analysis of co-expression of $R x f p 3$ mRNA and pERK immunolabeling in the OV detected a significantly higher level (Fig. 5a-b) in the A2-pref group than the vehicle group (29.5 \pm $0.96 \%$ versus $1.5 \pm 1.5 \% ; n=4 ; p<0.05$; Fig. 6e-f' $\mathbf{f}^{\prime \prime}$. In contrast, although an increased density of pERK immunopositive neurons was observed in the STMV, co-expression of pERK and $R x f p 3$ mRNA was not significantly different between the groups (A2-pref, $20.25 \pm 5.41 \%$; vehicle, $10 \pm 1.8 \% ; n=4 ; p=0.25$; Fig. 5g-h").

\section{Characterisation of $R x f p 3$ mRNA-expressing neurons in amygdala}

Multiplex fluorescence ISH was used to characterize key aspects of the neurochemical phenotype of $R x f p 3$ mRNA-expressing neurons. In the temporal extended amygdala, expression 
of Rxfp3, Oxtr and Slc32al mRNA was examined (Table 2). In the MeAD, $78 \%$ of the $R x f p 3$ mRNA-expressing neurons were Slc32al mRNA-positive (GABAergic) (Fig. 7a-a'); 5\% were Oxtr mRNA positive and $\sim 12 \%$ were positive for Oxtr and Slc32al mRNA. Only $\sim 5 \%$ of $R x f p 3$ mRNA-expressing neurons were negative for the other mRNA species (Fig. 7b).

In the MePV, 36\% of Rxfp3 mRNA-expressing neurons were Slc32al mRNA-positive (GABAergic) (Fig. 7c-c' $), \sim 20 \%$ were Oxtr mRNA-positive, and 11\% expressed all three mRNA species. Furthermore, $\sim 44 \%$ of $R x f p 3$ mRNA-expressing neurons expressed Oxtr mRNA (Fig. 7d). These data indicate that although a small proportion of $R x f p 3$ mRNAexpressing neurons in the MeAD express Oxtr, this population is larger in the MePV, where $\sim 31-44 \%$ of the Rxfp3 mRNA-expressing neurons express Oxtr mRNA. Conversely, almost half the Oxtr mRNA-expressing neurons in the MeAD expressed Rxfp3 mRNA. Similarly, the percentage of Oxtr mRNA-expressing neurons that co-expressed Rxfp3 mRNA in the MePV ranged from $42-69 \%$, probably due to variation in the total number of $R x f p 3 \mathrm{mRNA}$-expressing neurons (Table 3).

In the STMV, $43 \%$ of neurons co-expressed $R x f p 3$ and $O x t r$ mRNA (Fig. 7g-h) and $\sim 91 \%$ of these $R x f p 3$ mRNA-positive neurons were Slc32al mRNA-positive (Table 2 and Supplementary Fig. 2). In the OV, $\sim 38 \%$ of $R x f p 3$ mRNA-expressing neurons expressed Oxtr mRNA. Furthermore, $\sim 95 \%$ of $R x f p 3$ mRNA-positive neurons expressed Scl32al mRNA (i.e. GABAergic; Fig. 7e-f; Table 2; and Supplementary Fig. 2). These data indicate a significant proportion of Rxfp3 mRNA-positive neurons express Oxtr mRNA (38-43\%), and $\sim 89 \%$ of Oxtr mRNA-positive neurons in the OV and $\sim 39 \%$ in the STMV express Rxfp 3 mRNA (Table 3).

\section{DISCUSSION}

Social behaviour is characterized by a number of traits, including social recognition, motivation and reward, and is governed by complex brain processes (Dantzer et al. 1987; Gheusi et al. 1994; Hurlemann et al. 2010; Trezza et al. 2011; Pellissier et al. 2017). In this study, we demonstrate that activation of relaxin-3 receptor (RXFP3) signalling broadly throughout the forebrain impaired SRM of a familiar conspecific in adult male rats. We employed the truncated RXFP3 agonist, RXFP3-A2, which is selective for RXFP3 (Shabanpoor et al. 2012; Zhang et al. 2015) and has previously been administered icv to demonstrate RXFP3 influences on various modalities, including food intake (de Ávila et al. 2018), anxiety-like behaviour (Ryan et al. 2013a; Ma et al. 2017) and hippocampal-dependent spatial memory (Albert-Gascó et al. 2017).

Global RXFP3 activation decreased discrimination between novel and familiar conspecific rats, but did not alter social discrimination between a rat and an object, as all experimental groups exhibited a similar preference to explore a conspecific rat rather than an inanimate object. Interestingly, RXFP3-A2 infusion prior to the sociability test also impaired SRM at both 20 and 90 min post-infusion. A likely explanation for these findings is that RXPF3 signalling can inhibit memory formation when the agonist is present during the sociability test, and it can interfere with memory recall when present prior to and during the preference test. In both cases, RXFP3 agonist-treated rats were impaired during memory retrieval of familiar conspecifics, due to impaired memory formation and/or recall.

Complex brain circuits are involved in SRM processes (Scalia and Winans 1975; Landgraf et al. 1995; Alheid et al. 1998; Ferguson et al. 2001), and it is thought that the ventral CA1 is the primary repository or store for social-related memories (Okuyama et al. 2016). Amygdala nuclei and regions of ST are centrally involved in memory formation, and in particular, the MeA has been strongly associated with SRM regulation (Ferguson et al. 2001; Lukas et al. 2013; Gur et al. 2014), as it receives direct projections from centres involved in social processing (Scalia and Winans 1975). Notably, this social information is powerfully modulated by vasopressin (Everts and Koolhaas 1997; Veenema 2008; Gobrogge et al. 2009) and oxytocin (OT) systems. For example, OT gene knockout mice exhibit impaired SRM, and local infusions 
of OT into the MeA rescued this social behaviour (Everts and Koolhaas 1997; Winslow et al. 2000; Ferguson et al. 2001; Choleris et al. 2007; Veenema 2008). Furthermore, OT gene knockout mice exhibit decreased c-Fos expression in MeA, ST and medial preoptic area after a social interaction and memory test (Ferguson et al. 2001).

In an effort to determine whether RXFP3 signalling affected neural activity in the amygdala, we examined ERK activation patterns following icv RXFP3-A2 administration. Western blot analysis revealed increased pERK immunoreactivity in amygdala extracts 20 min post-agonist infusion, compared to levels in vehicle-treated and naïve, untreated rats. At 90 min post-agonist infusion, pERK immunoreactivity levels were equivalent to basal levels in these control rats. Thus, the peak in ERK phosphorylation in the amygdala was reached during social recognition and preference encounters, and highlights the relevance of ERK activation in social learning and memory (Peng et al. 2010; Giese and Mizuno 2013); as well as the consistent influence of the RLN3/RXFP3 system on the amygdala (Ma et al. 2007; Pereira et al. 2013; Santos et al. 2016).

Notably, in subsequent immunohistochemical studies, we detected an increase in pERKpositive neurons in the MeA. In line with this finding, pERK was increased in the MeA of mice with social deficits compared to controls, after a sociability and preference test (Faridar et al. 2014; Seese et al. 2014). Furthermore, in this model, oxytocin administration, improved social memory and reduced pERK levels in MeA, revealing a correlation between behavioural impairment and elevated pERK in MeA (Winslow et al. 2000; Winslow and Insel 2004). The observation that RXFP3 agonist treatment increased pERK levels in MeA and induced an impairment of SRM further supports the involvement of MeA signalling in social behaviour regulation. In anatomical studies, we confirmed the nature of the RLN3 innervation pattern within the amygdala (Santos et al. 2016) and noted several RLN3-positive nerve fibres making close contacts with pERK-immunopositive neurons in MeAD and MePV after the SRM task.

In assessing the co-expression of RXFP3 mRNA and mRNA encoding other relevant neural markers, in the MeAD we observed that most $R x f p 3$ mRNA-positive neurons were GABAergic (90\% Slc32al mRNA-positive), and 17\% also expressed Oxtr mRNA. Furthermore, $46 \%$ of the Oxtr mRNA-expressing neurons in MeAD co-expressed $R x f p 3$ mRNA. In contrast, in the MePV only $47 \%$ of $R x f p 3$ mRNA-positive neurons expressed Slc32al mRNA, while $>60 \%$ of Oxtr mRNA-positive neurons co-expressed $R x f p 3$ mRNA. Activation of the oxytocin receptor (OTR), which is coupled to the excitatory $\mathrm{G}_{\mathrm{q} / 11 \alpha}$ class of Gproteins that together with $\mathrm{G} \beta$ y stimulate the activity of phospholipase $\mathrm{C}-\beta$ isoform proteins (Shojo and Kaneko 2000), has been shown to produce neuronal excitation in the MeA (Terenzi and Ingram 2005), and presynaptic OTR activation promoted glutamate release (Mairesse et al. 2015). In contrast, RXFP3 is coupled to inhibitory $\mathrm{G}_{\text {ai/o }}$-proteins (Liu et al. 2003; Van der Westhuizen et al. 2007, 2010) and has been reported to hyperpolarize OT (and vasopressin) neurons in vitro (Kania et al. 2017). Thus, OTR and RXFP3 likely have directly opposing effects on the activity of some populations of amygdala neurons, and bidirectional regulatory mechanisms may exist between OT and RLN3 neurons, to regulate peptide release (Mairesse et al. 2015) and postsynaptic actions (Tyzio et al. 2006, 2014).

In RXFP3-A2-treated rats, we also detected increased pERK levels in the STMV and OV nuclei, which are strongly interconnected with the cortical amygdala and the MeA (GutierrezCastellanos et al. 2014; Cádiz-Moretti et al. 2016) and have been implicated in social interaction and social memory (Ferguson et al. 2001; Bannerman et al. 2004; Takahashi et al. 2004; Kuhlmann et al. 2005). In these regions, $R x f p 3$ mRNA was predominantly expressed by GABAergic neurons ( $80 \%$ Slc32al mRNA-positive), and $30 \%$ were Oxtr mRNA-positive. A major $(39 \%)$ and minor (16\%) proportion were Oxtr mRNA-positive in the MePV and the MeAD, respectively (Table 2). These findings suggest the RLN3/RXFP3 and OT/OTR systems may interact in the ST. In this regard, OT gene knockout mice displayed a specific decrease in 
neuronal activation in ST after a social interaction and memory test (Ferguson et al. 2001). All areas studied in these experiments are also known to be in rodents important processing centres which precede elicitation of aggressive behaviours; these include MeA, ST, LS and hippocampus (Nelson and Trainor 2007). In addition, aggression is known to impair recognition of social cues and enhance impulsivity (Kruk 1991). Thus, there is a possibility that social recognition memory modulation by the RLN3/RXFP3 system could elicit aggressive cues. Specially interesting is if this effect is dimorphic given its impact over the ST (Everts et al. 1997; Calvez et al. 2016).

Taken together, the current findings have demonstrated that RXFP3 is expressed by GABAergic neurons in the extended amygdala, consistent with reports in other brain areas (Richter et al. 2005; Blasiak et al. 2013; Haidar et al. 2017; Albert-Gascó et al. 2017), which implies an overall disinhibitory effect of the RLN3/RXFP3 system within the amygdala. Furthermore, the presence and proportions of Rxfp 3 and Oxtr mRNA-expressing neurons was broadly consistent across the different amygdaloid nuclei, suggesting a functional interaction between RXFP3 and OTR signalling, which warrants further investigation. Notably, OT has been implicated in the elicitation of social memory consolidation (Ferguson et al. 2001; Gur et al. 2014). As such, our results suggest a role for RLN3/RXFP3 signalling in modulating social memory, which might occur via rapid (direct and/or indirect) alterations in pERK and related signalling in GABAergic/peptidergic neurons within specific areas of the extended amygdala. Moreover, RXFP3 activation might be capable of modifying (antagonizing) the influence of OT/OTR signalling on MeA and ST neurons, in regulating (promoting) social behaviour, but further studies are now required to clarify the nature and complexity of this interaction.

\section{CONFLICT OF INTEREST}

All authors declare no conflict of interest.

\section{AUTHOR CONTRIBUTIONS}

HA-G, performed most experiments, wrote the first draft of the manuscript, compiled and edited the figures, and edited successive drafts of the manuscript

SS-S, helped perform the behavioural experiments, and conducted analysis of behavioural data

SM, helped design and perform the multiplex in situ hybridization experiments, and edited successive drafts of the manuscript

CG-D, helped perform the behavioural experiments and the combined multiplex in situ hybridization and immunofluorescence studies, and analysed these data

ALG, participated in the design of the experiments, and edited the figures and successive drafts of the manuscript

AMS-P, participated in the conception of the study and directed the research, and edited successive drafts of the manuscript

FEO-B, conceived the study and directed the research, designed the experiments, and edited successive drafts of the manuscript 


\section{REFERENCES}

Albert-Gascó H, García-Avilés Á, Moustafa S, Sánchez-Sarasua S, Gundlach AL, OluchaBordonau FE, Sánchez-Pérez AM (2017) Central relaxin-3 receptor (RXFP3) activation increases ERK phosphorylation in septal cholinergic neurons and impairs spatial working memory. Brain Struct Funct 222:449-463. doi: 10.1007/s00429-016-1227-8

Albert-Gascó H, Ma S, Ros-Bernal F, Sánchez-Pérez AM, Gundlach AL, Olucha-Bordonau FE (2018) GABAergic neurons in the rat medial septal complex express relaxin-3 receptor (RXFP3) mRNA. Front Neuroanat 11:133. doi: 10.3389/fnana.2017.00133

Alheid GF (2006) Extended Amygdala and Basal Forebrain. Ann N Y Acad Sci 985:185-205. doi: 10.1111/j.1749-6632.2003.tb07082.x

Alheid GFF, Beltramino CAA, de Olmos JSS, Forbes MSS, Swanson DJJ, Heimer L (1998) The neuronal organization of the supracapsular part of the stria terminalis in the rat: the dorsal component of the extended amygdala. Neuroscience 84:967-996. doi: $10.1016 / \mathrm{S} 0306-4522(97) 00560-5$

Arakawa H (2017) Involvement of serotonin and oxytocin in neural mechanism regulating amicable social signal in male mice: Implication for impaired recognition of amicable cues in BALB/c strain. Behav Neurosci 131:176-191. doi: 10.1037/bne0000191

Bannerman DM, Rawlins JN, McHugh SB, Deacon RM, Yee BK, Bast T, Zhang WN, Pothuizen HH, Feldon J (2004) Regional dissociations within the hippocampus memory and anxiety. Neurosci Biobehav Rev 28:273-283. doi: 10.1016/j.neubiorev.2004.03.004

Bathgate RA, Samuel CS, Burazin TC, Layfield S, Claasz AA, Reytomas IG, Dawson NF, Zhao C, Bond C, Summers RJ, Parry LJ, Wade JD, Tregear GW (2002) Human relaxin gene 3 (H3) and the equivalent mouse relaxin (M3) gene. Novel members of the relaxin peptide family. J Biol Chem 277:1148-1157. doi: 10.1074/jbc.M107882200

Baxter MG, Murray EA (2002) The amygdala and reward. Nat Rev Neurosci 3:563-573. doi: $10.1038 / \mathrm{nrn} 875$

Benarroch EE (2015) The amygdala: Functional organization and involvement in neurologic disorders. Neurology 84:313-324. doi: 10.1212/WNL.0000000000001171

Blasiak A, Blasiak T, Lewandowski MH, Hossain MA, Wade JD, Gundlach AL (2013) Relaxin-3 innervation of the intergeniculate leaflet of the rat thalamus - neuronal tracttracing and in vitro electrophysiological studies. Eur J Neurosci 37:1284-1294. doi: 10.1111/ejn.12155; 10.1111/ejn.12155

Bonnet L, Comte A, Tatu L, Millot J-L, Moulin T, Medeiros de Bustos E (2015) The role of the amygdala in the perception of positive emotions: an "intensity detector." Front Behav Neurosci 9:178. doi: 10.3389/fnbeh.2015.00178

Burazin TC, Bathgate RA, Macris M, Layfield S, Gundlach AL, Tregear GW (2002) Restricted, but abundant, expression of the novel rat gene-3 (R3) relaxin in the dorsal tegmental region of brain. J Neurochem 82:1553-1557. doi: https://doi.org/10.1046/j.14714159.2002.01114.x

Cádiz-Moretti B, Abellán-Álvaro M, Pardo-Bellver C, Martínez-García F, Lanuza E (2016) Afferent and efferent connections of the cortex-amygdala transition zone in mice. Front Neuroanat 10:125. doi: 10.3389/fnana.2016.00125

Calvez J, de Ávila C, Matte L-O, Guèvremont G, Gundlach AL, Timofeeva E (2016) Role of relaxin-3/RXFP3 system in stress-induced binge-like eating in female rats. Neuropharmacology 102:207-215. doi: 10.1016/j.neuropharm.2015.11.014

Choleris E, Little SR, Mong JA, Puram S V, Langer R, Pfaff DW (2007) Microparticle-based delivery of oxytocin receptor antisense DNA in the medial amygdala blocks social recognition in female mice. Proc Natl Acad Sci U S A 104:4670-5. doi: 10.1073/pnas.0700670104

Dantzer R, Bluthe R-M, Koob GF, Le Moal M (1987) Modulation of social memory in male 
rats by neurohypophyseal peptides. Psychopharmacology (Berl) 91:363-368. doi: 10.1007/BF00518192

Davis MC, Green MF, Lee J, Horan WP, Senturk D, Clarke AD, Marder SR (2014) Oxytocinaugmented social cognitive skills training in schizophrenia. Neuropsychopharmacology 39:2070-7. doi: 10.1038/npp.2014.68

de Ávila C, Chometton S, Lenglos C, Calvez J, Gundlach AL, Timofeeva E (2018) Differential effects of relaxin-3 and a selective relaxin-3 receptor agonist on food and water intake and hypothalamic neuronal activity in rats. Behav Brain Res 336:135-144. doi: 10.1016/j.bbr.2017.08.044

Everts HG, Koolhaas JM (1997) Lateral septal vasopressin in rats: role in social and object recognition? Brain Res 760:1-7

Everts HGJ, De Ruiter AJH, Koolhaas JM (1997) Differential Lateral Septal Vasopressin in Wild-type Rats: Correlation with Aggression. Horm Behav 31:136-144. doi: 10.1006/HBEH.1997.1375

Faridar A, Jones-Davis D, Rider E, Li J, Gobius I, Morcom L, Richards LJ, Sen S, Sherr EH (2014) Mapk/Erk activation in an animal model of social deficits shows a possible link to autism. Mol Autism 5:57. doi: 10.1186/2040-2392-5-57

Ferguson JN, Aldag JM, Insel TR, Young LJ (2001) Oxytocin in the medial amygdala is essential for social recognition in the mouse. J Neurosci 21:8278-85

Fox AS, Oler JA, Tromp DPMM, Fudge JL, Kalin NH (2015) Extending the amygdala in theories of threat processing. Trends Neurosci 38:319-329. doi: 10.1016/j.tins.2015.03.002

Gheusi G, Bluthé R-M, Goodall G, Dantzer R (1994) Social and individual recognition in rodents: Methodological aspects and neurobiological bases. Behav Processes 33:59-87. doi: 10.1016/0376-6357(94)90060-4

Giese KP, Mizuno K (2013) The roles of protein kinases in learning and memory. Learn Mem 20:540-552. doi: 10.1101/lm.028449.112

Gobrogge KL, Liu Y, Young LJ, Wang Z (2009) Anterior hypothalamic vasopressin regulates pair-bonding and drug-induced aggression in a monogamous rodent. Proc Natl Acad Sci U S A 106:19144-9. doi: 10.1073/pnas.0908620106

Green MF, Horan WP, Lee J (2015) Social cognition in schizophrenia. Nat Rev Neurosci 16:620-631. doi: 10.1038/nrn4005

Gupta R, Koscik TR, Bechara A, Tranel D (2011) The amygdala and decision-making. Neuropsychologia 49:760-766. doi: 10.1016/j.neuropsychologia.2010.09.029

Gur R, Tendler A, Wagner S (2014) Long-term social recognition memory is mediated by oxytocin-dependent synaptic plasticity in the medial amygdala. Biol Psychiatry 76:377386. doi: 10.1016/j.biopsych.2014.03.022

Gutiérrez-Castellanos N, Pardo-Bellver C, Martínez-García F, Lanuza E (2014) The vomeronasal cortex - afferent and efferent projections of the posteromedial cortical nucleus of the amygdala in mice. Eur J Neurosci 39:141-158. doi: 10.1111/ejn.12393

Haidar M, Guèvremont G, Zhang C, Bathgate RAD, Timofeeva E, Smith CM, Gundlach AL (2017) Relaxin-3 inputs target hippocampal interneurons and deletion of hilar relaxin-3 receptors in "floxed-RXFP3" mice impairs spatial memory. Hippocampus 27:529-546. doi: 10.1002/hipo.22709

Halls ML, van der Westhuizen ET, Bathgate R a D, Summers RJ (2007) Relaxin family peptide receptors--former orphans reunite with their parent ligands to activate multiple signalling pathways. Br J Pharmacol 150:677-691. doi: 10.1038/sj.bjp.0707140

Happé F, Conway JR (2016) Recent progress in understanding skills and impairments in social cognition. Curr Opin Pediatr 28:736-742. doi: 10.1097/MOP.0000000000000417

Hatalski CG, Guirguis C, Baram TZ (1998) Corticotropin releasing factor mRNA expression 
in the hypothalamic paraventricular nucleus and the central nucleus of the amygdala is modulated by repeated acute stress in the immature rat. J Neuroendocrinol 10:663-9

Hitti FL, Siegelbaum SA (2014) The hippocampal CA2 region is essential for social memory. Nature 508:88-92. doi: 10.1038/nature13028

Hurlemann R, Patin A, Onur OA, Cohen MX, Baumgartner T, Metzler S, Dziobek I, Gallinat J, Wagner M, Maier W, Kendrick KM (2010) Oxytocin enhances amygdala-dependent, socially reinforced learning and emotional empathy in humans. J Neurosci 30:4999-5007. doi: 10.1523/JNEUROSCI.5538-09.2010

Kania A, Gugula A, Grabowiecka A, de Ávila C, Blasiak T, Rajfur Z, Lewandowski MH, Hess G, Timofeeva E, Gundlach AL, Blasiak A (2017) Inhibition of oxytocin and vasopressin neuron activity in rat hypothalamic paraventricular nucleus by relaxin-3-RXFP3 signalling. J Physiol 595:3425-3447. doi: 10.1113/JP273787

Kocan M, Sarwar M, Hossain M a., Wade JD, Summers RJ (2014) Signalling profiles of H3 relaxin, $\mathrm{H} 2$ relaxin and $\mathrm{R} 3(\mathrm{~B} \Delta 23-27) \mathrm{R} / \mathrm{I} 5$ acting at the relaxin family peptide receptor 3 (RXFP3). Br J Pharmacol 171:2827-2841. doi: 10.1111/bph.12623

Korzan WJ, Summers TR, Ronan PJ, Renner KJ, Summers CH (2001) The role of monoaminergic nuclei during aggression and sympathetic social signaling. Brain Behav Evol 57:317-27

Kruk MR (1991) Ethology and pharmacology of hypothalamic aggression in the rat. Neurosci Biobehav Rev 15:527-538. doi: 10.1016/S0149-7634(05)80144-7

Kuhlmann S, Piel M, Wolf OT (2005) Impaired memory retrieval after psychosocial stress in healthy young men. J Neurosci 25:2977-82. doi: 10.1523/JNEUROSCI.5139-04.2005

Landgraf R, Gerstberger R, Montkowski A, Probst JC, Wotjak CT, Holsboer F, Engelmann M (1995) V1 vasopressin receptor antisense oligodeoxynucleotide into septum reduces vasopressin binding, social discrimination abilities, and anxiety-related behavior in rats. $\mathrm{J}$ Neurosci 15:4250-8

Lee LC, Rajkumar R, Dawe GS (2014) Selective lesioning of nucleus incertus with corticotropin releasing factor-saporin conjugate. Brain Res 1543:179-190. doi: 10.1016/j.brainres.2013.11.021

Lenglos C, Mitra A, Guèvremont G, Timofeeva E (2014) Regulation of expression of relaxin3 and its receptor RXFP3 in the brain of diet-induced obese rats. Neuropeptides 48:119132. doi: 10.1016/j.npep.2014.02.002

Liu C, Eriste E, Sutton S, Chen J, Roland B, Kuei C, Farmer N, Jörnvall H, Sillard R, Lovenberg TW (2003) Identification of Relaxin-3/INSL7 as an Endogenous Ligand for the Orphan G-protein-coupled Receptor GPCR135. J Biol Chem 278:50754-50764. doi: 10.1074/jbc.M308995200

Lukas M, Toth I, Veenema AH, Neumann ID (2013) Oxytocin mediates rodent social memory within the lateral septum and the medial amygdala depending on the relevance of the social stimulus: Male juvenile versus female adult conspecifics. Psychoneuroendocrinology 38:916-926. doi: 10.1016/j.psyneuen.2012.09.018

Ma S, Bonaventure P, Ferraro T, Shen PJ, Burazin TCD, Bathgate R a D, Liu C, Tregear GW, Sutton SW, Gundlach a. L (2007) Relaxin-3 in GABA projection neurons of nucleus incertus suggests widespread influence on forebrain circuits via G-protein-coupled receptor-135 in the rat. Neuroscience 144:165-190. doi: 10.1016/j.neuroscience.2006.08.072

Ma S, Smith CM, Blasiak A, Gundlach AL (2017) Distribution, physiology and pharmacology of relaxin-3/RXFP3 systems in brain. $\mathrm{Br} \mathrm{J}$ Pharmacol 174:1034-1048. doi: 10.1111/bph.13659

Mairesse J, Gatta E, Reynaert M-L, Marrocco J, Morley-Fletcher S, Soichot M, Deruyter L, Camp G Van, Bouwalerh H, Fagioli F, Pittaluga A, Allorge D, Nicoletti F, Maccari S 
(2015) Activation of presynaptic oxytocin receptors enhances glutamate release in the ventral hippocampus of prenatally restraint stressed rats. Psychoneuroendocrinology 62:36-46. doi: 10.1016/j.psyneuen.2015.07.005

Maski K, Holbrook H, Manoach D, Hanson E, Kapur K, Stickgold R (2015) Sleep dependent memory consolidation in children with autism spectrum disorder. Sleep 38:1955-1963. doi: $10.5665 /$ sleep. 5248

Nelson RJ, Trainor BC (2007) Neural mechanisms of aggression. Nat Rev Neurosci 8:536-546. doi: $10.1038 / \mathrm{nrn} 2174$

Okuyama T, Kitamura T, Roy DS, Itohara S, Tonegawa S (2016) Ventral CA1 neurons store social memory. Science 353:1536-1541. doi: 10.1126/science.aaf7003

Olucha-Bordonau FE, Fortes-Marco L, Otero-García M, Lanuza E, Martínez-García F (2014) The amygdala structure and function. In: Paxinos $\mathrm{G}$ (ed) The rat nervous system. IV Edition. pp 441-490

Olucha-Bordonau FE, Teruel V, Barcia-González J, Ruiz-Torner A, Valverde-Navarro AA, Martínez-Soriano F (2003) Cytoarchitecture and efferent projections of the nucleus incertus of the rat. J Comp Neurol 464:62-97. doi: 10.1002/cne.10774

Paxinos GG, Watson C (2014) The Rat Brain in Stereotaxic Coordinates. Academic Press, San Dicego $(\mathrm{Ca})$

Pellissier LP, Gandía J, Laboute T, Becker JAJ, Le Merrer J (2017) $\mu$ opioid receptor, social behaviour and autism spectrum disorder: reward matters. Br J Pharmacol 16:620-631. doi: 10.1111/bph. 13808

Peng S, Zhang Y, Zhang J, Wang H, Ren B (2010) ERK in learning and memory: a review of recent research. Int J Mol Sci 11:222-32. doi: 10.3390/ijms11010222

Pereira CW, Santos FN, Sanchez-Perez AM, Otero-Garcia M, Marchioro M, Ma S, Gundlach AL, Olucha-Bordonau FE (2013) Electrolytic lesion of the nucleus incertus retards extinction of auditory conditioned fear. Behav Brain Res 247:201-210. doi: 10.1016/j.bbr.2013.03.025; 10.1016/j.bbr.2013.03.025

Pro-Sistiaga P, Mohedano-Moriano A, Ubeda-Bañon I, Del Mar Arroyo-Jimenez M, Marcos P, Artacho-Pérula E, Crespo C, Insausti R, Martinez-Marcos A (2007) Convergence of olfactory and vomeronasal projections in the rat basal telencephalon. J Comp Neurol 504:346-62. doi: 10.1002/cne.21455

Rasia-Filho AA, Londero RG, Achaval M (2000) Functional activities of the amygdala: an overview. J Psychiatry Neurosci 25:14-23

Richter K, Wolf G, Engelmann M (2005) Social recognition memory requires two stages of protein synthesis in mice. Learn Mem 12:407-13. doi: 10.1101/1m.97505

Ryan PJ, Buchler E, Shabanpoor F, Hossain MA, Wade JD, Lawrence AJ, Gundlach AL (2013a) Central relaxin-3 receptor (RXFP3) activation decreases anxiety- and depressivelike behaviours in the rat. Behav Brain Res 244:142-151. doi: 10.1016/j.bbr.2013.01.034; 10.1016/j.bbr.2013.01.034

Ryan PJ, Kastman HE, Krstew E V., Rosengren KJ, Hossain MA, Churilov L, Wade JD, Gundlach AL, Lawrence AJ (2013b) Relaxin-3/RXFP3 system regulates alcohol-seeking. Proc Natl Acad Sci U S A 110:20789-20794. doi: 10.1073/pnas.1317807110

Ryan PJ, Ma S, Olucha-Bordonau FE, Gundlach AL (2011) Nucleus incertus an emerging modulatory role in arousal, stress and memory. Neurosci Biobehav Rev 35:1326-1341. doi: 10.1016/j.neubiorev.2011.02.004

Santos FN, Pereira CW, Sánchez-Pérez AM, Otero-García M, Ma SK, Gundlach AL, OluchaBordonau FE (2016) Comparative distribution of relaxin-3 inputs and calcium-binding protein-positive neurons in rat amygdala. Front Neuroanat 10:. doi: 10.3389/fnana.2016.00036

Scalia F, Winans SS (1975) The differential projections of the olfactory bulb and accessory 
olfactory bulb in mammals. J Comp Neurol 161:31-55. doi: 10.1002/cne.901610105

Schindelin J, Arganda-Carreras I, Frise E, Kaynig V, Longair M, Pietzsch T, Preibisch S, Rueden C, Saalfeld S, Schmid B, Tinevez J-Y, White DJ, Hartenstein V, Eliceiri K, Tomancak P, Cardona A (2012) Fiji: an open-source platform for biological-image analysis. Nat Methods 9:676-682. doi: 10.1038/nmeth.2019

Seese RR, Maske AR, Lynch G, Gall CM (2014) Long-term memory deficits are associated with elevated synaptic ERK1/2 activation and reversed by mGluR5 antagonism in an animal model of autism. Neuropsychopharmacology 39:1664-73. doi: 10.1038/npp.2014.13

Servan A, Brunelin J, Poulet E (2017) The effects of oxytocin on social cognition in borderline personality disorder. Encephale 44:46-51. doi: 10.1016/j.encep.2017.11.001

Seymour B, Dolan R (2008) Emotion, decision making, and the amygdala. Neuron 58:662671. doi: 10.1016/j.neuron.2008.05.020

Shabanpoor F, Akhter Hossain M, Ryan PJ, Belgi A, Layfield S, Kocan M, Zhang S, Samuel CS, Gundlach AL, Bathgate RAD, Separovic F, Wade JD (2012) Minimization of human relaxin-3 leading to high-affinity analogues with increased selectivity for relaxin-family peptide 3 receptor (RXFP3) over RXFP1. J Med Chem 55:1671-81. doi: $10.1021 / \mathrm{jm} 201505 \mathrm{p}$

Shojo H, Kaneko Y (2000) Characterization and Expression of Oxytocin and the Oxytocin Receptor. Mol Genet Metab 71:552-558. doi: 10.1006/MGME.2000.3094

Smith SM, Vale WW (2006) The role of the hypothalamic-pituitary-adrenal axis in neuroendocrine responses to stress. Dialogues Clin Neurosci 8:383-95

Takahashi T, Ikeda K, Ishikawa M, Tsukasaki T, Nakama D, Tanida S, Kameda T (2004) Social stress-induced cortisol elevation acutely impairs social memory in humans. Neurosci Lett 363:125-130. doi: 10.1016/J.NEULET.2004.03.062

Tanaka M, Iijima N, Miyamoto Y, Fukusumi S, Itoh Y, Ozawa H, Ibata Y (2005) Neurons expressing relaxin 3/INSL 7 in the nucleus incertus respond to stress. Eur J Neurosci 21:1659-1670. doi: 10.1111/j.1460-9568.2005.03980.x

Terenzi MG, Ingram CD (2005) Oxytocin-induced excitation of neurones in the rat central and medial amygdaloid nuclei. Neuroscience 134:345-354. doi: 10.1016/j.neuroscience.2005.04.004

Trainor BC, Crean KK, Fry WHD, Sweeney C (2010) Activation of extracellular signalregulated kinases in social behavior circuits during resident-intruder aggression tests. Neuroscience 165:325-36. doi: 10.1016/j.neuroscience.2009.10.050

Trezza V, Campolongo P, Vanderschuren L (2011) Evaluating the rewarding nature of social interactions in laboratory animals. Dev Cogn Neurosci 1:444-458. doi: 10.1016/J.DCN.2011.05.007

Tyzio R, Cossart R, Khalilov I, Minlebaev M, Hübner CA, Represa A, Ben-Ari Y, Khazipov R (2006) Maternal oxytocin triggers a transient inhibitory switch in GABA signaling in the fetal brain during delivery. Science 314:1788-92. doi: 10.1126/science.1133212

Tyzio R, Nardou R, Ferrari DC, Tsintsadze T, Shahrokhi A, Eftekhari S, Khalilov I, Tsintsadze V, Brouchoud C, Chazal G, Lemonnier E, Lozovaya N, Burnashev N, Ben-Ari Y (2014) Oxytocin-mediated GABA inhibition during delivery attenuates autism pathogenesis in rodent offspring. Science 343:675-9. doi: 10.1126/science.1247190

Van der Westhuizen ET, Christopoulos A, Sexton PM, Wade JD, Summers RJ (2010) H2 relaxin is a biased ligand relative to $\mathrm{H} 3$ relaxin at the relaxin family peptide receptor 3 (RXFP3). Mol Pharmacol 77:759-772. doi: 10.1124/mol.109.061432

Van der Westhuizen ET Van Der, Werry TD, Sexton PM, Summers RJ (2007) The Relaxin Family Peptide Receptor 3 Activates Extracellular Signal-Regulated Kinase $1 / 2$ through a Protein Kinase C-Dependent Mechanism. Mol Pharmacol 71:1618-1629. doi: 
10.1124/mol.106.032763.growth

Veenema AH (2008) Central vasopressin and oxytocin release: regulation of complex social behaviours. Prog Brain Res 170:261-276. doi: 10.1016/S0079-6123(08)00422-6

Vuilleumier P, Sander D (2008) Trust and valence processing in the amygdala. Soc Cogn Affect Neurosci 3:299-302. doi: 10.1093/scan/nsn045

Williams DL, Goldstein G, Minshew NJ (2006) The profile of memory function in children with autism. Neuropsychology 20:21-9. doi: 10.1037/0894-4105.20.1.21

Winslow JT, Ferguson JN, Young LJ, Hearn EF, Matzuk MM, Insel TR, Winslow JT (2000) Social amnesia in mice lacking the oxytocin gene. Nat Genet 25:284-288. doi: $10.1038 / 77040$

Winslow JT, Insel TR (2004) Neuroendocrine basis of social recognition. Curr Opin Neurobiol 14:248-253. doi: 10.1016/j.conb.2004.03.009

Zhang C, Chua BE, Yang A, Shabanpoor F, Hossain MA, Wade JD, Rosengren KJ, Smith CM, Gundlach AL (2015) Central relaxin-3 receptor (RXFP3) activation reduces elevated, but not basal, anxiety-like behaviour in C57BL/6J mice. Behav Brain Res 292:125-32. doi: 10.1016/j.bbr.2015.06.010 


\section{TABLES}

Table 1. Relative density of pERK-immunopositive neurons in different areas of amygdala

Brain area Abbreviation Bregma Vehicle RXFP3-A2- RXFP3- P

(mm) Pref A2-Soc value

\begin{tabular}{|c|c|c|c|c|c|c|}
\hline $\begin{array}{l}\text { Anteromedial } \\
\text { nucleus of the } \\
\text { stria terminalis }\end{array}$ & STMA & $\begin{array}{c}0.84 \text { to }- \\
0.12\end{array}$ & $100 \pm 18.5$ & $136 \pm 13.1$ & $101 \pm 7.9$ & 0.078 \\
\hline $\begin{array}{l}\text { Ventromedial } \\
\text { nucleus of the } \\
\text { stria terminalis }\end{array}$ & STMV & $\begin{array}{c}0.36 \text { to }- \\
0.36\end{array}$ & $100 \pm 21.9$ & $275 \pm 27.2^{*}$ & $\begin{array}{c}196 \pm \\
49.0\end{array}$ & 0.004 \\
\hline Oval nucleus & OV & $\begin{array}{c}0.24 \text { to }- \\
0.24\end{array}$ & $100 \pm 10.7$ & $199 \pm 29.0^{*}$ & $118 \pm 8.5$ & 0.021 \\
\hline $\begin{array}{l}\text { Anteromedial } \\
\text { medial } \\
\text { amygdala }\end{array}$ & MeAV & $\begin{array}{c}-1.8 \text { to }- \\
2.52\end{array}$ & $100 \pm 23.6$ & $85 \pm 11.2$ & $\begin{array}{c}161 \pm \\
44.6\end{array}$ & 0.207 \\
\hline $\begin{array}{l}\text { Anterodorsal } \\
\text { medial } \\
\text { amygdala }\end{array}$ & MeAD & $\begin{array}{c}-1.8 \text { to }- \\
2.4\end{array}$ & $100 \pm 15.4$ & $190 \pm 28.0^{*}$ & $\begin{array}{c}100.6 \pm \\
21.5\end{array}$ & 0.017 \\
\hline $\begin{array}{l}\text { Posteroventral } \\
\text { medial } \\
\text { amygdala }\end{array}$ & $\mathrm{MePV}$ & $\begin{array}{l}-2.64 \text { to- } \\
3.6\end{array}$ & $100 \pm 19.4$ & $177 \pm 18.9^{*}$ & $\begin{array}{c}133.4 \pm \\
22.3\end{array}$ & 0.037 \\
\hline $\begin{array}{l}\text { Posteroventral } \\
\text { medial } \\
\text { amygdala }\end{array}$ & MePD & $\begin{array}{c}-2.52 \text { to }- \\
3.48\end{array}$ & $100 \pm 13.0$ & $146 \pm 20.7$ & $\begin{array}{l}122 \pm \\
17.36\end{array}$ & 0.204 \\
\hline $\begin{array}{l}\text { Central } \\
\text { amygdala }\end{array}$ & $\mathrm{CeA}$ & $\begin{array}{c}-1.56 \text { to }- \\
3.36\end{array}$ & $100 \pm 13.3$ & $197 \pm 22.5^{*}$ & $\begin{array}{l}110 \pm \\
17.09\end{array}$ & 0.003 \\
\hline $\begin{array}{l}\text { Basolateral } \\
\text { amygdala }\end{array}$ & BLA & $\begin{array}{c}-1.72 \text { to }- \\
3.12\end{array}$ & $100 \pm 14.0$ & $89 \pm 12.1$ & $75 \pm 2.8$ & $\mathbf{0 . 3 7 9}$ \\
\hline
\end{tabular}


Table 2. Proportion of $R x f p 3$ mRNA-expressing neurons in different areas of amygdala that coexpress other mRNA species

\begin{tabular}{|c|c|c|c|c|c|}
\hline \multicolumn{6}{|c|}{ MeAD } \\
\hline \multirow[t]{2}{*}{$\begin{array}{c}\text { Rxfp3-Oxtr- } \\
\text { Slc32a1 }\end{array}$} & Rxfp3-Oxtr & $\begin{array}{l}\text { Rxfp3- } \\
\text { Slc32a1 }\end{array}$ & Triple & $R x f p 3$ & Total $R x f p 3$ \\
\hline & 5 & 85 & 13 & 6 & 111 \\
\hline \multicolumn{6}{|c|}{ MePV } \\
\hline \multirow[t]{2}{*}{$\begin{array}{c}\text { Rxfp3-Oxtr- } \\
\text { Slc32a1 }\end{array}$} & Rxfp3-Oxtr & $\begin{array}{l}\text { Rxfp3- } \\
\text { Slc32a1 }\end{array}$ & Triple & $R x f p 3$ & Total $R x f p 3$ \\
\hline & 18 & 32 & 10 & 29 & 89 \\
\hline \multirow[t]{2}{*}{ Rxfp3-Oxtr 1} & & Rxfp3-Oxtr & & $R x f p 3$ & Total $R x f p 3$ \\
\hline & & 44 & & 55 & 98 \\
\hline \multirow[t]{2}{*}{ Rxfp3-Oxtr 2} & & Rxfp3-Oxtr & & $R x f p 3$ & Total $R x f p 3$ \\
\hline & & 27 & & 37 & 64 \\
\hline \multicolumn{6}{|c|}{$\mathbf{O V}$} \\
\hline \multirow[t]{2}{*}{ Rxfp3-Oxtr } & & Rxfp3-Oxtr & & $R x f p 3$ & Total $R x f p 3$ \\
\hline & & 29 & & 47 & 76 \\
\hline \multirow[t]{2}{*}{ Rxfp3-Slc32a1 } & & Rxfp3-Slc32a1 & & $R x f p 3$ & Total $R x f p 3$ \\
\hline & & 118 & & 6 & 124 \\
\hline \multicolumn{6}{|c|}{ STMV } \\
\hline \multirow[t]{2}{*}{ Rxfp3-Oxtr } & & Rxfp3/Oxtr & & $R x f p 3$ & Total $R x f p 3$ \\
\hline & & 10 & & 13 & 30 \\
\hline \multirow[t]{2}{*}{ Rxfp3-Slc32a1 } & & Rxfp3/Slc32a1 & & $R x f p 3$ & Total $R x f p 3$ \\
\hline & & 30 & & 3 & 33 \\
\hline
\end{tabular}


Table 3. Proportion of Oxtr mRNA-expressing neurons that co-express Rxfp 3 mRNA in different areas of amygdala

\section{MePV}

\begin{tabular}{|c|c|c|}
\hline Probe Combination & $R x f p 3 / O x t r$ & Total Oxtr \\
\hline Rxfp3-Oxtr-Slc32a1 & 22 & 66 \\
\hline Rxfp3-Oxtr 1 & 52 & 77 \\
\hline Rxfp3-Oxtr 2 & 33 & 48 \\
\hline \multicolumn{3}{|c|}{ MeAD } \\
\hline & $R x f p 3 / O x t r$ & Total Oxtr \\
\hline Rxfp3-Oxtr-Slc32a1 & 18 & 66 \\
\hline \multicolumn{3}{|c|}{$O V$} \\
\hline \multirow{2}{*}{ Rxfp3-Oxtr } & Rxfp3/Oxtr & Total Oxtr \\
\hline & 52 & 58 \\
\hline \multicolumn{3}{|c|}{$\overline{S T M V}$} \\
\hline \multirow{2}{*}{ Rxfp3-Oxtr } & $R x f p 3 / O x t r$ & Total Oxtr \\
\hline & 27 & 68 \\
\hline
\end{tabular}




\section{FIGURE CAPTIONS}

Fig. 1 Social recognition memory is impaired after RXFP3 agonist infusion. (a) Timeline of 3chamber social interaction and memory and sociability tests, with infusion times indicated (black arrows). (b) Preference index for the sociability and (c) preference tests of experimental groups. First contact latency for the (d) sociability and (e) preference tests. ns, not significant; $* \mathrm{p}<0.05 ; * * * \mathrm{p}<0.001 ; * * * * \mathrm{p}<0.0001$

Fig. 2 pERK immunoreactivity is increased in amygdala after RXFP3 agonist infusion. (a, b) Rats sacrificed $20 \mathrm{~min}$ after icv infusion of RXFP3-A2 $(\sim 1 \mathrm{nmol}$; red bar) displayed significantly increased pERK in the amygdala area, compared to vehicle-treated (aCSF, white bar) and naïve rats (black bar). (c, d) Rats sacrificed 90 min after infusion exhibited similar pERK levels to those in the control groups. ${ }^{*} \mathrm{p}<0.05 ; * * * \mathrm{p}<0.001$.

Fig. 3 pERK immunostaining in the MeA after social encounters. (a) Schematic illustrating the MeAD and MePV nuclei analysed. (b) Density of pERK-stained neurons was significantly increased in A2-Pref rats (green bar) compared to vehicle (dashed black line). Representative images of pERK immunostaining in the MeAD of (c) vehicle, (d) A2-Pref and (e) A2-Soc groups. Representative images of pERK immunostaining in the MePV of (f) vehicle, (g) A2Pref and (h) A2-Soc groups. (i, j) RLN3-immunoreactive fibres (green) make close contact with pERK-positive neurons (red) in the (I) MeAD (i', single plane orthogonal view) and (j) MePV ( $\mathbf{j}^{\prime}$, single plane orthogonal view) of A2-Pref rats. ${ }^{*} \mathrm{p}<0.05 ;{ }^{*} \mathrm{p}<0.01$. Scale bars: 100 $\mu \mathrm{m}(\mathbf{c}), 10 \mu \mathrm{m}\left(\mathbf{i}, \mathbf{i}^{\prime}\right)$.

Fig. 4 pERK immunostaining in the extended amygdala after social encounters. (a) Schematic illustrating the STMV, STMA and OV nuclei in the extended amygdala analyzed. (b) Density of pERK-stained cells was significantly increased in A2-Pref rats (green bars) compared to vehicle (dashed black line). Representative images of pERK immunostaining in the STMV of (c) vehicle, (d) A2-Pref and (e) A2-Soc rats. Representative images of pERK immunostaining in the OV of (f) vehicle, (g) A2-Pref and (h) A2-Soc rats. (i, j) RLN3-immunoreactive fibres (green) making close contact with pERK-positive neurons (red) in the (i) STMV (i', single plane orthogonal view) and (j) OV (j', single plane orthogonal view) of A2-Pref rats. ${ }^{*} \mathrm{p}<0.05$; ${ }^{*} \mathrm{p}$ $<0.01$. Scale bars: $100 \mu \mathrm{m}(\mathbf{c}), 10 \mu \mathrm{m}\left(\mathbf{i}, \mathbf{i}^{\prime}\right)$.

Fig. 5 pERK immunofluorescence and $R x f p 3$ mRNA co-expression in neurons of the extended amygdala. (a) Ratio of Rxfp3 mRNA-positive neurons, which display pERK immunoreactivity, (b) Ratio of pERK-immunopositive neurons that express Rxfp3 mRNA. ${ }^{*} p<0.05$; ns: not significant.

Fig. 6. pERK immunofluorescence and $R x f p 3 \mathrm{mRNA}$ co-expression in neurons of the extended amygdala. (a-b) Representative images illustrating pERK-immunopositive neurons, $\left(\mathbf{a}^{\prime}-\mathbf{b}^{\prime}\right)$ Rxfp3 mRNA and merged signal (a' $\left.\mathbf{a}^{\prime \prime}, \mathbf{b}^{\prime \prime}\right)$ from vehicle and A2-pref group rats in the MeAD. (c, d) Representative images illustrating pERK-immunopositive neurons, (c', $\left.\mathbf{d}^{\prime}\right)$ Rxfp3 mRNA and merged signal $\left(\mathbf{c}^{\prime \prime}, \mathbf{d}^{\prime}\right)$ from vehicle and A2-pref group rats in the MePV. (e, f) Representative images illustrating pERK immunopositive neurons, $\left(\mathbf{e}^{\prime}, \mathbf{f}^{\prime}\right)$ Rxfp3 mRNA and merged signal $\left(\mathbf{e}^{\prime \prime}, \mathbf{f}^{\prime \prime}\right)$ from vehicle and A2-pref group rats in the OV. (g, h) Representative

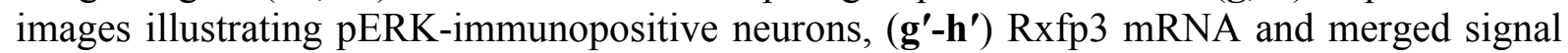
$\left(\mathbf{g}^{\prime \prime}, \mathbf{h}^{\prime \prime}\right)$ from vehicle and A2-pref group rats in the STMV. Scale bar: $25 \mu \mathrm{m}(\mathbf{a})$. 
Fig. 7 Characterization of the neurochemical phenotype of Rxfp3 mRNA-positive neurons in the extended amygdala. (a) Schematic illustrating Rxfp 3 mRNA distribution and co-expression with Oxtr and Slc32al mRNA in the MeAD. (a', b) Representative images of fluorescent ISH and quantification of co-expression percentages indicated (lower right corner). (c) Schematic illustrating Rxfp 3 mRNA distribution and co-expression with Oxtr and Slc32al mRNA in the $\mathrm{MePV}\left(\mathbf{c}^{\prime}, \mathbf{d}\right)$. (e) Schematic illustrating Rxfp3 mRNA distribution and co-expression with Oxtr mRNA in the STOV. (e', f) Representative images of fluorescent ISH and co-expression percentages. (g) Schematic illustrating $R x f p 3$ mRNA distribution and co-expression with Oxtr mRNA in the STMV $\left(\mathbf{g}^{\prime}, \mathbf{h}\right)$. Scale bar: $100 \mu \mathrm{m}\left(\mathbf{a}^{\prime}\right), 10 \mu \mathrm{m}(\mathbf{b})$.

\section{Supplementary Figure Captions}

Supplementary Fig. 1. (a) Heat maps for the three-chamber social interaction paradigm for the sociability and preference tests. Percentages on the corners of the trackings refer to the average percentage time spent in each room. Percentages on the heat maps next to "subject", "object" $u$ "conspecifics" refer to the average percentage time spent sniffing. (b) Percentage time sniffing the conspecific rat (green bars) and inanimate object (black bars), or (c) the familiar (white bars) and novel rat (red bars) for the different experimental groups. ${ }^{*} \mathrm{p}<0.05$, $* * * * \mathrm{p}<0.0001$, ns: not significant.

Supplementary Fig. 2. Characterisation of the neurochemical phenotype of Rxfp3 mRNApositive neurons in STMV an STOV. (a) Schematic illustrating Rxfp3 distribution and coexpression with Oxtr mRNA in STMV (a'and b) Representative fluorescent images.

Representative images of fluorescent ISH and quantification of co-expression percentages indicated (lower right corner). (c) Schematic illustrating Rxfp3 mRNA distribution and coexpression with Oxtr and Slc32al mRNAs in the MePV. (c' ${ }^{\prime}$ and d). Scale barS: $100 \mu \mathrm{m}\left(\mathrm{a}^{\prime}\right)$, $10 \mu \mathrm{m}(\mathrm{b})$

Supplementary Fig. 3. pERK immunostaining in the CeA after social encounters. (a) Schematic illustrating the CeA sub-nuclei analysed. (b) Density of pERK-stained neurons was significantly increased in A2-Pref rats (red bars) compared to vehicle treated rats (dashed black line). Representative images of pERK immunostaining in the CeA of (c) vehicle, (d) A2-Pref and (e) A2-Soc group rats. ${ }^{*} p<0.05 ; *$; $<0.01$. Scale bar: $100 \mu \mathrm{m}$ (c). 